\title{
Hypopituitarism Resulting from an Intrasellar Carotid Aneurysm
}

\author{
T. C. Ooi and N.A. Russell
}

\begin{abstract}
We report a 74 year old lady who presented with an exceedingly rare combination of an internal carotid artery aneurysm which was almost entirely intrasellar and associated with hypopituitarism but no neurological deficits. Such a lesion could be misdiagnosed as a pituitary tumour with serious consequences, if surgery is attempted without prior carotid angiography.
\end{abstract}

RÉSUMÉ: Hypopituitarisme secondaire à un anévrysme intrasellaire de la carotide Nous rapportons le cas d'une femme de 74 ans que se présentait avec la très rare association d'un anévrysme de la carotide interne presqu'entièrement intrasellaire et qui était associé à un hypopituitarisme sans déficit neurologique. Une telle lésion pourrait être confondue à une tumeur pituitaire, avec des conséquences majeures si une angiographie carotidienne préalable n'a pas été faite.

Can. J. Neurol. Sci. 1986; 13:70-7I

Intrasellar aneurysm of the carotid artery is an uncommon condition which may mimic a pituitary tumour. We describe a patient who had hypopituitarism but no neurological deficit from such an aneurysm.

\section{CASE RePORT}

A 74 year old lady complained of fatigue, frontal headaches and episodic confusion of 3 months duration. Three years earlier, a skull $\mathrm{X}$-ray was said to show an enlarged sella turcica. She had received furosemide for ankle swelling and thyroxine for hypothyroidism for several years.

On examination, she was confused. Blood pressure was $120 / 70$ with no postural drop. Her thyroid was normal and she had no galactorrhoea or signs of acromegaly. Except for the initial confusion which cleared, there was no neurological deficit. In particular, her fundi were normal and there was no visual field defect.

Initial laboratory results revealed a hyponatraemia of $120 \mathrm{mmol} / \mathrm{l}$. Serum potassium was $4.4 \mathrm{mmol} / \mathrm{l}$ and total $\mathrm{CO}_{2}, 25 \mathrm{mmol} / \mathrm{l}$. A skull $X$-ray showed enlargement of the sella turcica, with curvilinear calcifications in the sella and suprasellar regions (Figure 1). A CT scan demonstrated an intrasellar enhancing lesion measuring $1.8 \mathrm{~cm}$ in diameter, with extension above the sella by only $2 \mathrm{~mm}$ (Figure 2). Carotid angiography revealed a large aneurysm arising from the intracavernous portion of the left internal carotid artery, filling the sella (Figure 1).

Her serum LH and FSH were undetectable, indicating deficiency of these hormones, as high values are normally expected in the menopausal state. Serum T4 and TSH were within normal limits (on $0.15 \mathrm{mg}$ T4 daily). Serum cortisol was $311.9 \mathrm{nmol} / \mathrm{l}(11.3 \mathrm{microg} / \mathrm{dl})$ rising to $659.6 \mathrm{nmol} / \mathrm{l}(23.9 \mathrm{microg} / \mathrm{dl})$, sixty minutes after administration of synthetic ACTH (Cortrosyn, $0.25 \mathrm{mg}$ ), indicating normal adrenal cortical function. However, when insulin hypoglycemia was induced (serum glucose dropped to $1.71 \mathrm{mmol} / \mathrm{l}(31 \mathrm{mg} / \mathrm{dl})$ and she became sweaty and weak) serum cortisol rose inadequately from $215.3 \mathrm{nmol} / 1(7.8 \mathrm{microg} / \mathrm{dl})$ to $265.0 \mathrm{nmol} / /(9.6 \mathrm{microg} / \mathrm{dl})$, indicating partial ACTH deficiency. Serum growth hormone rose from $3.2 \mathrm{microg} / \mathrm{l}$ to $11.2 \mathrm{microg} / \mathrm{l}$. Basal serum prolactin was high (182.2 microg/l) and fell slightly to around $120-150 \mathrm{microg} / \mathrm{l}$ with hypoglycemia.

Since the patient was elderly and the aneurysm intact and within the cavernous sinus, surgery was not recommended. She was discharged on hydrocortisone and thyroxine replacement therapy.

\section{Discussion}

There have been several reported cases of suprasellar and parasellar aneurysms, associated with hypopituitarism (1-4). In almost all cases, there were neurological deficits as well, particularly visual field defects. Our patient presented with an exceedingly rare combination of an internal carotid artery aneurysm which was almost entirely intrasellar associated with hypopituitarism but no neurological deficits. The only other report of a similar case is that of Cartlidge and Shaw. ${ }^{5}$ In the series of White and Ballantine,' there were several cases of intrasellar aneurysms but they were all associated with visual field defects and other neurological deficits. In addition, the presence of hypopituitarism in these cases was not shown by direct hormone assay.

From the Division of Endocrinology and Metabolism (Dr. Ooi), the Division of Neurosurgery (Dr. Russell), Ottawa Civic Hospital, University of Ottawa Received July 4, 1985. Accepted September 23, 1985

Reprint requests to: Dr. T. C. Ooi, Division of Endocrinology and Metabolism. Ottawa Civic Hospital, 1053 Carling Avenue, Ottawa. Ontario, Canada KIY 4E9 


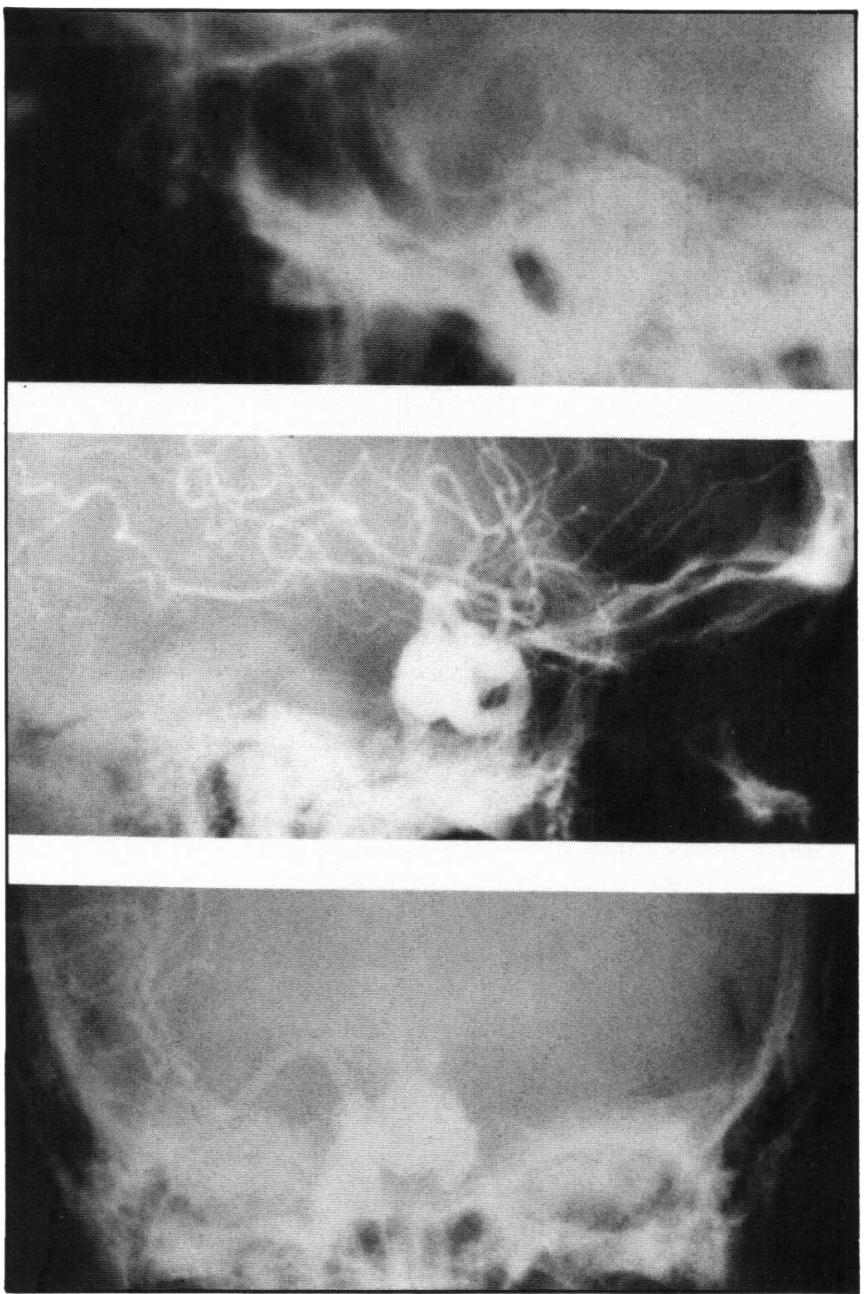

Figure 1 - Plain skull X-ray (lateral view) showing ballooned sella (upper)and left internal carotid arteriogram showing intrasellar aneurysm (middle and lower).

A patient presenting in the manner of our case is particularly liable to a misdiagnosis of a pituitary tumour. The elevation in serum prolactin level might be misinterpreted as evidence for prolactin secretion by such a tumour. We interpreted the hyperprolactinemia as being due to pituitary stalk compression.

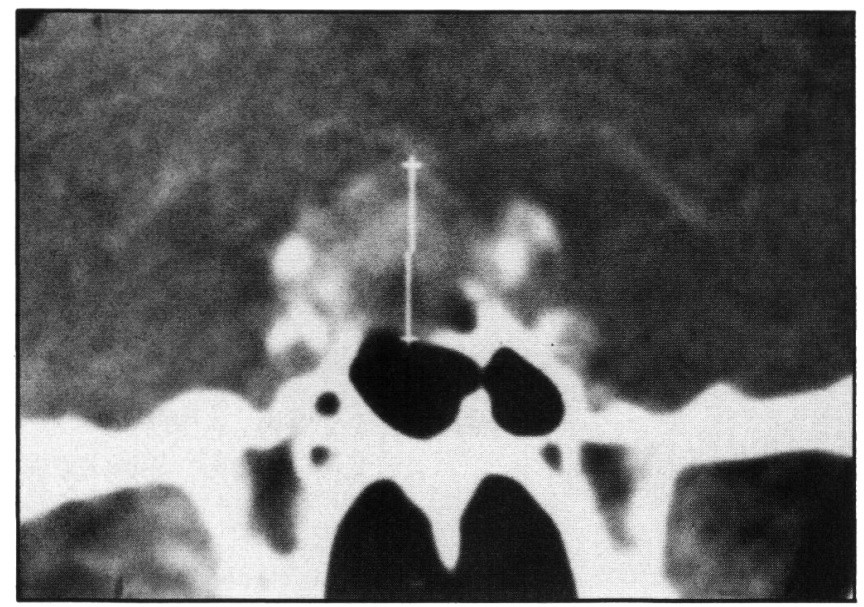

Figure $2-$ Enhanced CTscan(coronal section) showing an intrasellarenhancing mass with some suprasellar extension and sellar floor erosion. Height of mass as indicated by line was $1.8 \mathrm{~cm}$.

The CT scan did not clearly indicate that the mass was an aneurysm instead of a pituitary tumour. CT scanners with higher resolution may unequivocally show a sellar mass to be an aneurysm. However, the surgical consequences are so grave that when any doubt exists, angiography must be performed. At the present time, we would prefer the less dangerous digital venous subtraction method to carotid angiography. However, the latter would be recommended if the diagnosis remained in doubt.

\section{REFERENCES}

1. White JC, Ballantine HT Jr. Intrasellar aneurysms simulating hypophyseal tumours. J Neurosurg 1961; 18: 34-50.

2. Dussault J, Plamandon C, Volpe R. Aneurysms of the internal carotid artery simulating pituitary tumours. Canad Med Assoc J 1969; 101: 785-790.

3. Shantharam VV, Clift GV. Suprasellar aneurysm. An unusual cause of hypopituitarism. JAMA 1974; 229: 1473.

4. Verbalis JG, Nelson PB, Robinson AG. Reversible panhypopituitarism caused by a suprasellar aneurysm: The contribution of mass effect to pituitary dysfunction. Neurosurgery 1982; 10: 604-611.

5. Cartlidge NEF, Shaw DA. Intrasellar aneurysm with subarachnoid hemorrhage and hypopituitarism. J Neurosurg 1972;36: 640-643. 